\title{
SPECIÁLIS VESZÉLYFORRÁSOK AZ ORVOSI ROBOTIKÁBAN
}

\section{SPECIAL HAZARDS IN MEDICAL ROBOTICS}

\author{
Pausits Péter \\ Óbudai Egyetem Biztonságtudományi Doktori Iskola, Cím: H-1081 Magyarország, \\ Budapest, Népszínház utca 8.; Óbudai Egyetem Robottechnikai Szakkollégium Cím: \\ H-1032 Magyarország, Budapest, Kiscelli utca 78. Telefon: +36-30-2099288, \\ peter.pausits@irob.uni-obuda.hu
}

\begin{abstract}
Throughout the history of many industries one of the most significant was the saving of human life and treating diseases. The medical instruments come to direct or indirect contact with human body due to their nature. During the researches many new methods emerged that interacts with not only with patients but also the operators of such instruments like the x-ray, laser. With the development of control systems the medical robots appeared that can prevent human mistakes and therefore decreases the number of malpractices and also their consequensces. However with their appearances new risks came up unlike anything before. In order to resolve those risks new safetyengineering standards had to be developed and used, but the surgical medical instruments doesn't have unified international regulations that could aid their research, production and application. With this researh our goal is to define the surgical robotics.
\end{abstract}

Keywords: hazards, shared workspace, medical device standard, surgical robots.

\section{Összefoglalás}

A történelem során a számos iparág fejlődése közül az egyik legnagyobb hangsúlyt az emberi élet megmentése és sérülések betegségek megfelelö kezelése kapta. Az orvosi eszközök más iparági eszközökkel ellentétben, sajátosságukból adódóan közvetlen vagy közvetett kapcsolatba kerülnek az emberi szervezettel. A fejlődés során olyan eljárások jelentek meg, amelyek már nem csak a beteggel, hanem az eszköz kezelöszemélyzetével is interakcióba kerülnek, mint a röntgen sugár, lézer vagy az ultrahang. Az ipari szabályozástechnika fejlődésével párhuzamosan megjelentek az orvosi robotok is, amelyek számos emberi tényezőt képesek kiszürni és ezáltal az orvosi mühibák számát és következményét csökkenteni, de megjelenésükkel újabb veszélyek merültek fel, amelyek korábban nem voltak jellemzőek. Ennek érdekében számos biztonságtechnikai szabvány került kidolgozásra és alkalmazásra, de a sebészeti orvosi robotokra még jelenleg nincsen egységes nemzetközi elöírás, amely elősegítené a fejlesztésüket, gyártásukat és felhasználásukat. Ezen kutatással a sebészeti robotika meghatározását segítjük elő.

Kulcsszavak: veszélyek, osztott munkatér, orvosi eszköz szabványok, sebészeti robot.

\section{Bevezetés}

Az elmúlt 30 évben számos orvosi eszköz fejlődése kapott még kiemeltebb szere- pet, amelyek közül jelen kutatásunk az orvosi robotokkal és biztonságtechnikájukkal foglalkozik. Az orvosi eszközök és kiemelten az orvosi robotok működése során szá- 
mos hasonlóság figyelhető meg az ipari robotokéval, viszont a ,félkész termék" esetünkben az ember. Az orvosi robotok veszélyforrásainak elemzésénél alapvetően az az ISO 10218-1:2011 „Robots and robotic devices - Safety requirements for industrial robots" szabványosítást vettem alapul, amely rögzíti a kollaboránsban müködő ipari robotok veszélyforrásait és a sérülések elkerülésére vonatkozó ajánlásokat. A robotok orvosi beavatkozásit, müveleteit tekintve megvizsgáltuk, hogy a beavatkozástól minőségétől függően (behatoló, nem behatoló) milyen veszély források jelentkezhetnek a beavatkozás során [1]. A behatoló sebészeti eszközök esetén tovább bontható a testnyíláson keresztül, illetve az emberi szöveten keresztül behatoló eszközökre, amelyek természetüknél fogva külön kategóriát képviselnek.

A kutatás során csoportosítottuk ezen szempontok szerint a jelenleg piacon és publikált kutatás alatt lévő orvosi robotokat, amely alapján szükíthetők és kategorizálhatók azon eszközök, amelyekre jelenleg nem létezik teljes körü biztonságtechnikai elöírás.

A veszélyekből fakadó bekövetkezhető sérüléseket nem csupán betegen kell vizsgálnunk, hanem a beavatkozással közvetlenül együtt dolgozó személyzeten is, hiszen számos esetben nagyobb kockázatnak vannak kitéve a berendezést kezelő személyek.

\section{Vizsgált berendezések}

A kutatás során 112 olyan orvosi eszközt vizsgáltunk, amelyeket tervezésük és felhasználásuk során valamilyen már létező szabvány elöírásai szerint készítettek, viszont egyelöre - a sebészeti robotokra vonatkozó biztonságtechnikai szabvány hiánya miatt - nem tisztázott, hogy sebészeti beavatkozó robotnak kell-e tekintenünk vagy sem. A sebészeti robotok estén figyelembe vehető kategóriák:

\subsection{Endoszkóp eszközök}

Az endoszkópok esetén egy testnyíláson keresztül behatoló eszközről beszélünk, amelyet elsősorban diagnosztikai eszközként tartunk nyílván, de egyes típusai képesek szövetmintát gyüjteni a vizsgált területről. Így azon típusai, amelyek csak diagnosztikát végeznek (PillCam) azok nem tekinthető sebészeti robotnak, viszont a mintagyüjtők (Invendoscope, FLEX, Cyclops, i-Snake, KidsArm) esetén megfigyelhetők az egyes, sebészeti robotokra jellemző veszélyek.

\subsection{Laparoszkópiás beavatkozás}

A behatoló sebészeti robotokat tekintve a legtöbb esetben laparoszkópiás beavatkozást végző robottal találkozhatunk (da Vinci Surgical System, DEX robot, ROSA, ViKY, AESOP, Zeus, ALF-X, Bitrack, Laparobot, SurgiBot, SOFIE, SPRINT, AQrate, NEDO), amely a minimál invazív sebészetnek (MIS) egyik legelterjedtebb fajtája [2]. Az eljárás lényege, hogy minimális szöveti metszésen keresztül juttatunk a szervezetbe hosszú nyéllel rendelkező manipulátorokat és a mütétéi terület vizuális megjelenítéséhez szükséges optikai eszközt [3]. Ennek következtében sokkal kisebb megterhelés éri a szervezetet, viszont a müvelettel járó új veszélyforrások jelentkeznek. A mütét elvégzéséhez a hasüreg felfújását kell alkalmaznunk. A beavatkozás során váratlan vérzés következhet be, amikor azonnal váltani kell nyílt sebészetre.

\subsection{Urológiai beavatkozás}

Az urológiás beavatkozásra fejlesztett sebészeti robotokat (Probot, BioBot, MrBot, Concentric Tube Robots) transurethralis húgyhólyag tumor (TUR) eltávolítására alkalmazzák, amely egyik kiemelt következménye a potenciavesztés és a mosófolyadék által okozott szövődmény. A TUR beavatkozás a MIS beavatkozás szintén egyik fajtája. 


\subsection{Katéterezés}

A katéterezés során kiemelt problémát jelent a katéter megfelelő navigációja. A navigációhoz folyamatos röntgensugarat alkalmaznak, amely a vizsgálat ideje alatt nem okoz maradandó károsodást a betegben, viszont a müveletet végrehajtó orvos a munkaideje alatt állandó veszélynek van kitéve. Robot alkalmazása (CASCADE, HeartLander, Amigo) esetén elkerülhetö, hogy a kezelö személyzet egy védett területen tartózkodjon, amíg a beavatkozás tart. A robot által végzett navigáció segít olyan területekre történő eljutásban, amelyet kézi beavatkozással nem tudnánk végrehajtani.

\subsection{Transzplantáció}

A transzplantációs orvosi robot (ARTAS) műveletét tekintve börön keresztül behatoló sebészeti robotnak tekinthetö, amely robotokat elsősorban haj átültetésre alkalmaznak.

\section{Veszélyforrások}

A vizsgálat során megállapítható volt a sebészeti robotokra jellemző veszélyforrások tekintetében számos hasonlóság az ipari robotokra jellemző veszélyforrásokkal [1]:

- Normális vagy nem szándékolt robot kar alkatrészének mozgása;

- Külső tengelyek normális vagy nem szándékolt mozgása;

- Mozgatott termék vagy tárgy kiejtése;

- Erő visszacsatolás hiánya;

- Erőátviteli berendezés meghibásodása;

- Berendezés merevedése a testben;

- Felfújás közbeni nyomás;

- Nagy feszültség vagy nagy frekvencia alkalmazása;

- Energiaellátás nem tervezett megszünése;

- Jelátalakítás sebessége;

- Hosszú távú zajszennyezettség;

- Mechanikai kapcsolatok, kötőelemek, alkatrészek váratlan megállása vagy kiadása;
- Nem szándékolt mozgás az irányítói oldalról;

- Élő szervezetre káros anyagok felhasználása;

- Leválasztott szövet nem megfelelő helyre történő bejutása;

- Beavatkozó nem szándékolt müvelete;

- Robotkarok találkozása;

- Forgási sebesség;

- Nem szándékolt szorítási erő;

- Nem szándékolt szorítási időintervallum;

- End-effector cseréje közbeni pozícionálás;

- A beavatkozó nem szándékolt mozgása;

- Alkatrészek nagy sebességgel történő mozgatása.

Az ipari megmunkálás esetén az megmunkált anyag szilárdságától függően megfelelöen rögzíthető a félkész termék, illetve külső fizikai behatás nélkül a munkadarab nem tud elmozdulni a pozíciójából. Az orvosi beavatkozás során az emberi szövet és idegrendszer sajátosságából adódóan váratlan elmozdulást fordulhat elö, amely különös veszélyt jelent a beavatkozás során.

\section{Sebészeti invazív robotok is- mérvei}

A felkutatott orvosi robotok veszélyeit vizsgálva és a jelenleg már megjelent biztonságtechnikai szabványokat figyelembe véve tovább redukálható azon orvosi robotok száma és típusa, amelyre még nem vonatkozik érvényes biztonságtechnikai irányelv.

Egyértelmüen megfogalmazható, hogy sebészeti robotika szempontjából csak azon eszközök tekinthetőek robotnak, amelyek nem közvetlen emberi erővel müködnek, hanem csak minimum master-slave üzemmódban hajtják végre a kezelő utasításait és saját pozícionálóval, tartószerkezettel és beavatkozókkal rendelkeznek. 


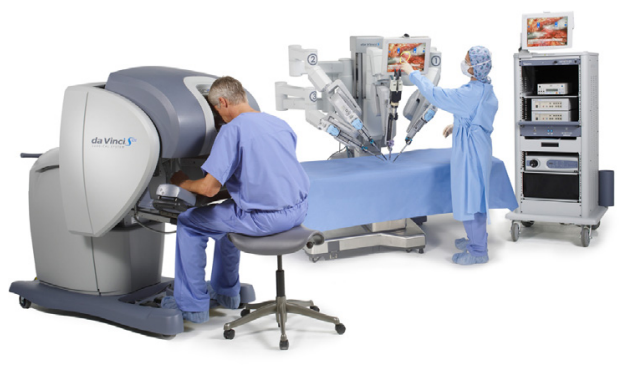

1. ábra. Master-slave üzemmódban müködő da Vinci sebészeti robot [4]

A sebészeti robotok klasszikus értelemben vett sebészeti beavatkozást hajtanak végre, azaz az emberi szöveten keresztül jutnak be a mütéti területre, amelynél elengedhetetlen az emberi szövet minimális metszése. Metszés nélküli beavatkozást, azaz a nagyfrekvenciás beavatkozással müködő orvosi eszközöket ebböl a szempontból (X-RAY, MRI, CT) nem tekintjük sebészeti invazív robotnak, mert ezen eljárásokra már léteznek megfelelö biztonságtechnikai elöírások.

Az endoszkóp típusú eszközök azon csoportját, amely mintavétel gyüjtésére is alkalmas azon eszközök tartozhatnak ezen csoportba.

A fogászati szájsebészeti eljárásokra szintén széles körü biztonságtechnikai szabványosítás létezik, így szintén nem tekinthető az invazív sebészeti beavatkozásnak.

\section{Következtetések}

A kutatás során megállapítható volt, hogy a klasszikus értelemben vett robot megfogalmazás sokkal pontosabb definíciót igényel. Továbbá a sebészeti invazív beavatkozásokat tekintve a felmerülő veszélyforrások egy részletes kutatást igényeltek, amely alapján pontosan meghatározható azon orvosi eszközök köre, amely még nem rendelkezik biztonságtechnikai szabványnyal.

A kutatás során feltártuk azon veszélyforrásokat, amelyek nagy hasonlóságot mutatnak az orvosi robotok és az osztott munkatérben müködő ipari robotok között. Ennek eredményeként megfogalmazódtak olyan veszélyek, amelyek az emberi szövet sajátosságaiból adódóan más területen használatos robotok felhasználása során nem merülhettek fel, viszont kiemelt figyelmet kell rájuk fordítani a sebészeti invazív robotok esetén.

\section{Szakirodalmi hivatkozások}

[1] Haidegger T., és Rudas I. J.: From Concept to Market: Surgical Robot Development", Handbook of Research on Advancements in Robotics and Mechatronics, 2014, 242.

[2] Pausits P., Szogi G., Nagy D. A., M. Nallbani, Rudas I. J. és Haidegger T.: Identification of Hazards in Invasive/Surgical Robotics. IEEE IROS Workshop, Hamburg, 2015.

[3] Rosenblatt A., Bollens R. and Espinoza Cohen B.: General Laparoscopic Information (Serias Springer Tracts in Manual of Laparoscopic Urology). Spriger-Verlag, 2008, 1-17.

[4] Forrás: http://intuitivesurgical.com (letöltés dátuma: 2016.02.11.) 